\title{
Knowledge, opinions and practices of healthcare workers related to infant feeding in the context of HIV
}

\author{
Liska Janse van Rensburg ${ }^{a, *}$, Riette $\mathrm{Nel}^{b, 1}$, Corinna M. Walsh ${ }^{a, 2}$ \\ a Department of Nutrition and Dietetics, Faculty of Health Sciences, University of the Free State, PO Box 339, \\ Bloemfontein, 9300, South Africa \\ ${ }^{\mathrm{b}}$ Department of Biostatistics, Faculty of Health Sciences, University of the Free State, PO Box 339, Bloemfontein, \\ 9300, South Africa
}

\section{A R T I C L E I N F O}

Article history:

Received 16 March 2015

Accepted 3 December 2015

Available online 18 March 2016

Keywords:

Infant feeding

HIV

Knowledge

Opinion

Practice

Healthcare

\begin{abstract}
A B S T R A C T
Background: The importance of healthcare workers' guidance for women infected with human immunodeficiency virus (HIV) regarding infant feeding practices cannot be overemphasised.

Objective: To determine the knowledge, opinions and practices of healthcare workers in maternity wards in a regional hospital in Bloemfontein, Free State Province, South Africa, regarding infant feeding in the context of HIV.

Methods: For this descriptive cross-sectional study, all the healthcare workers in the maternity wards of Pelonomi Regional Hospital who voluntarily gave their consent during the scheduled meetings ( $n=64)$, were enrolled and handed over the self-administered questionnaires.

Results: Only $14 \%$ of the respondents considered themselves to be experts in HIV and infant feeding. Approximately $97 \%$ felt that breastfeeding was an excellent feeding choice provided proper guidelines were followed. However, $10 \%$ indicated that formula feeding is the safest feeding option. $45 \%$ stated that heat-treated breast milk is a good infant feeding option; however, $29 \%$ considered it a good infant feeding option but it requires too much work. Only 6\% could comprehensively explain the term "exclusive breastfeeding" as per World Health Organisation (WHO) definition. Confusion existed regarding the period for which an infant could be breastfed according to the newest WHO guidelines, with only $26 \%$ providing the correct answer. Twenty per cent reported that no risk exists for HIV transmission via breastfeeding if all the necessary guidelines are followed.

Conclusion: Healthcare workers' knowledge did not conform favourably with the current WHO guidelines. These healthcare workers were actively involved in the care of patients in the maternity wards where HIV-infected mothers regularly seek counselling on infant feeding matters.
\end{abstract}

E-mail addresses: JansevanRensburgL1@ufs.ac.za (L. Janse van Rensburg), gnbsmn@ufs.ac.za (R. Nel), WalshCM@ufs.ac.za (C.M. Walsh).

${ }^{1}$ Tel.: +2751 4013116

2 Tel.: +27 51401 3818, +27 0832976030 (mobile).

* Corresponding author. Tel.: +27 $514013320,+27847009552$ (mobile).

Peer review under responsibility of Johannesburg University.

http://dx.doi.org/10.1016/j.hsag.2015.12.001

1025-9848/@ 2015 The Authors. Publishing services by Elsevier B.V. on behalf of Johannesburg University. This is an open access article under the CC BY-NC-ND license (http://creativecommons.org/licenses/by-nc-nd/4.0/). 


\begin{abstract}
A B S T R A K
Agtergrond: Die waarde van die leiding wat gesondheidsorgwerkers aan vroue wat met menslike immuniteitsgebrekvirus (MIV) geïnfekteer is, ten opsigte van babavoeding praktyke verskaf, kan nie oorbeklemtoon word nie.

Doel: Om die kennis, opinies en praktyke van gesondheidsorgwerkers in kraamsale in 'n plaaslike hospitaal in Bloemfontein, Vrystaat Provinsie, Suid-Afrika, ten opsigte van babavoeding in die konteks van MIV te bepaal.

Metodes: Vir hierdie beskrywende dwarssnit studie was alle gesondheidsorgwerkers in die kraamsale van Pelonomi Streekshospitaal wat vrywillig gedurende afgespreekte vergaderings ingeligte toestemming verskaf het $(n=64)$, in die studie ingesluit en het die selftoegediende vraelyste oorhandig.

Resultate: Slegs 14\% van die respondente het hulself as kundiges in MIV en babavoeding geag. Bykans $97 \%$ het gevoel dat borsvoeding 'n uitstekende voedingsopsie is indien gepaste riglyne gevolg word. Tog het $10 \%$ aangedui dat formule voeding die veiligste voedingsopsie is. $45 \%$ het verklaar dat die gebruik van hitte-behandelde borsmelk 'n goeie opsie is; terwyl $29 \%$ aangedui het dat dit 'n goeie opsie is maar dat dit te veel werk vereis. Slegs $6 \%$ kon die term "eksklusiewe borsvoeding" soos deur die Wêreld Gesondheidsorganisasie (WGO) gedefinieer, omvattend beskryf. Verwarring het bestaan rakende die periode wat ' $n$ baba geborsvoed kan word volgens die nuutste WGO riglyne, met slegs $26 \%$ wat die korrekte antwoord verskaf het. Twintig persent het aangedui dat daar geen risiko van MIV oordrag via borsvoeding bestaan indien die nodige riglyne gevolg word nie.

Gevolgtrekking: Gesondheidsorgwerkers se kennis het nie gunstig met die huidige WGO riglyne vergelyk nie, inaggenome dat hierdie gesondheidsorgwerkers in kraamsale werk waar MIV-geïnfekteerde vroue op 'n gereelde basis advies rakende babavoeding soek.

(C) 2015 The Authors. Publishing services by Elsevier B.V. on behalf of Johannesburg University. This is an open access article under the CC BY-NC-ND license (http:// creativecommons.org/licenses/by-nc-nd/4.0/).
\end{abstract}

\section{Introduction}

A central role of healthcare workers is to provide effective counselling to their patients. This places the responsibility on them to ensure that their health knowledge is adequate and can be conveyed clearly. Many women in Sub-Saharan African countries accept the recommendations of healthcare workers as final, and the opinions and advice given by them are highly respected (Piwoz et al., 2006). Therefore, healthcare workers counselling HIV-infected mothers about infant feeding can play a major role in the outcome of the choice of feeding. Healthcare workers' inadequate knowledge regarding the newest guidelines for the prevention of mother-to-child transmission (PMTCT) of human immunodeficiency virus (HIV) can negatively impact the knowledge and practices of their patients (Vallely et al. 2013) to the detriment of the health of the infant. Some key challenges in the PMTCT programmes have been attributed to poor training of healthcare workers (Koricho, Moland, \& Blystad, 2010) coupled by the poor counselling by these healthcare workers to the mothers (Mnyani \& McIntyre, 2013).

\subsection{Problem statement}

One of the core features of any PMTCT programme is to assist HIV-infected mothers in their decision making process regarding the mode of infant feeding as well as to provide them with the necessary on-going support during infant feeding. The choice of whether to formula feed or to breastfeed cannot be made without careful consideration of each woman's unique household, medical, socioeconomic and cultural circumstances. Mixed feeding is associated with a higher risk of mortality compared to exclusive breastfeeding (WHO, 2010a), however the practice of exclusive breastfeeding is not common in developing countries (Cai, Wardlaw, \& Brown, 2012). Consequently, it is of the utmost importance that HIV-infected mothers understand exactly how to maximise the possibility of HIV-free child survival by adopting correct infant feeding practices.

The impact of counselling by healthcare workers cannot be overemphasised. Potential gaps in their knowledge can, however, interfere with its success. Therefore in order to plan effective interventions, it is important to determine the current status of HIV and PMTCT counselling in South Africa. The main aim of this paper is to describe the existing knowledge, opinions and practices of healthcare workers regarding infant feeding in the context of HIV; and, compare the same with the latest World Health Organisation (WHO) Guidelines on HIV and Infant Feeding (WHO, 2010a) as well as other relevant literature.

\section{Research methods and design}

In this case a descriptive cross-sectional study design was employed and 64 healthcare workers were enrolled from the 
maternity wards of Pelonomi Regional Hospital in the Free State. Their knowledge, opinions and practices relating to HIV and infant feeding were assessed by means of selfadministered questionnaires, as all healthcare workers were literate. To increase the response rate, an incentive was made available in the form of a shopping voucher which was awarded to one respondent by utilising a lucky draw method. However, the value of the study and their voluntary participation was explained in detail at the outset. Questionnaires were distributed in March 2011 to all healthcare workers present during arranged meetings with the first author; however, the participation was voluntary.

\subsection{Data collection procedure}

Multiple-choice as well as open-ended questions were utilised to assess knowledge, opinions and practices regarding infant feeding in the context of HIV. The questions relating to knowledge were primarily based on the 2010 WHO Guidelines on HIV and Infant Feeding (WHO, 2010a).

\subsection{Data analysis}

Descriptive statistics, namely frequencies and percentages for categorical data and medians and percentiles for continuous data, were calculated. Associations between variables were calculated and described using 95\% confidence intervals (CI) for differences in medians or percentages. All analyses were performed by the Department of Biostatistics at the University of the Free State.

\section{Results}

A response rate of $49.6 \%$ (64/129) was obtained. Most of the participating healthcare workers were nursing personnel $(\mathrm{n}=47 ; 73.4 \%$ ), while doctors and dieticians represented $20.3 \%$ $(n=13)$ and $6.3 \%(n=4)$ of the sample, respectively.

\subsection{Knowledge relating to infant feeding in the context of HIV}

Only nine (14.1\%) of the healthcare workers considered themselves to be an expert on the issues of HIV and infant feeding. In general, most of the respondents ( $n=58 ; 90.6 \%$ ) were aware that infants who are formula-fed have a higher risk for morbidity and mortality; while four of them (6.3\%) reported this statement to be false, another two (3.1\%) expressed their ignorance.

The recommended period of EBF was well-known to the majority of the healthcare workers, since 95.3\% $(n=61)$ reported this to be six months. However, confusion existed when they were asked to indicate for which time period a mother can breastfeed in total, which includes breastfeeding exclusively (for the first six months) plus non-exclusively (after the introduction of complementary foods at six months) according to the new 2010 WHO Guidelines on HIV and Infant Feeding (WHO, 2010a). Only 17 (26.6\%) respondents were aware that an HIV-infected mother can breastfeed her baby up to the age of one year and stop only when a nutritionally adequate diet without breast milk can be provided.

Overall, most ( $n=47 ; 73.4 \%$ ) of the respondents were aware of the increased risk of HIV transmission if the guidelines are not followed and that of a lowered risk if the guidelines are followed ( $n=45 ; 70.3 \%)$. Of these healthcare workers, almost one in five ( $n=13 ; 20.3 \%$ ) reported that there is no risk of transmission if the mother follow the guidelines.

Regarding the issue of mixed feeding, most of the respondents ( $n=57 ; 89.1 \%$ ) were correct in reporting that this practice increases the risk of HIV transmission, barring a total of $10.9 \%(n=7)$ of respondents who either disagreed or who were unable to provide an answer. Responses relating to the perceived meaning of "exclusive breastfeeding" are summarised in Table 1 . Out of the 64 respondents, 60 of them (93.8\%) attempted to explain the term, while four (6.2\%) were unaware of what the term "exclusive breastfeeding" refers to.

\subsection{Opinions relating to infant feeding in the context of HIV}

Responses relating to the opinions of the healthcare workers are summarised in Table 2. Almost all the respondents (96.9\%) expressed their positive views towards HIV-infected mothers who want to breastfeed their infants. However, when enquired about their opinions regarding HIV-infected mothers wanting to formula feed their infants, $10.9 \%$ indicated this to be the safest choice as it would ensure that the baby remains uninfected and thus healthy. Most of the respondents thought that feeding heat-treated expressed breast milk to HIVexposed infants was a good option (45.3\%).

Healthcare workers were asked to express their opinion regarding the new guidelines in South Africa which promote breastfeeding as a choice for infant feeding by HIV-infected mothers. Most of the respondents (89.1\%) expressed a positive attitude towards this policy change, but $6.3 \%$ of them indicated that they would like the distribution of free formula milk reinstated in South Africa.

\subsection{Practices relating to infant feeding in the context of HIV}

When asked how often they gave advice to HIV-infected women regarding HIV and infant feeding, almost half of the

Table 1 - Participating healthcare workers' $(n=60)$ responses relating to the explanation of "exclusive breastfeeding",

\begin{tabular}{lrr} 
Explanation of "exclusive breastfeeding" & $\mathrm{n}$ & \multicolumn{1}{c}{$\%$} \\
\hline $\begin{array}{l}\text { 1. Only breast milk should be given } \\
\begin{array}{l}\text { 2. Only breast milk should be given AND } \\
\text { to breastfeed on demand }\end{array}\end{array}$ & 42 & 70.0 \\
$\begin{array}{l}\text { 3. Only breast milk should be given AND that } \\
\text { no pacifiers should be given }\end{array}$ & 1 & 1.7 \\
$\begin{array}{l}\text { 4. Only breast milk should be given AND to } \\
\text { breastfeed on demand AND that no } \\
\text { pacifiers should be given (correct response }\end{array}$ & 4 & 6.7 \\
$\begin{array}{l}\text { as per WHO guidelines) } \\
\text { 5. Unrelated or incorrect answer }\end{array}$ & 8 & 13.3 \\
\hline
\end{tabular}


Table 2 - Participants' opinions relating to infant feeding in the context of HIV.

\begin{tabular}{|c|c|c|}
\hline Questions to test opinions of participants & $\mathrm{n}$ & $\%$ \\
\hline \multicolumn{3}{|l|}{ 1. Regarding breastfeeding } \\
\hline $\begin{array}{l}\text { a. Women should not breastfeed since the } \\
\text { risk of transmission remains }\end{array}$ & 0 & 0 \\
\hline $\begin{array}{l}\text { b. Breastfeeding is an excellent feeding } \\
\text { choice if guidelines are followed }\end{array}$ & 62 & 96.9 \\
\hline c. Other & 2 & 3.1 \\
\hline \multicolumn{3}{|l|}{ 2. Regarding formula feeding } \\
\hline $\begin{array}{l}\text { a. Safest way to feed since there is no HIV } \\
\text { transmission risk }\end{array}$ & 7 & 10.9 \\
\hline $\begin{array}{l}\text { b. It may only be promoted in women meeting } \\
\text { the } \text { AFASS }^{\text {a }} \text { criteria for safe formula feeding }\end{array}$ & 49 & 76.6 \\
\hline c. Others & 8 & 12.5 \\
\hline \multicolumn{3}{|l|}{ 3. Regarding heat-treated expressed breast milk } \\
\hline a. Good idea & 29 & 45.3 \\
\hline b. Bad idea & 8 & 12.5 \\
\hline c. Good idea, but not feasible or sustainable & 19 & 29.7 \\
\hline d. Do not know & 5 & 7.8 \\
\hline \multicolumn{3}{|l|}{$\begin{array}{l}\text { 4. Regarding new South African PMTCT guidelines } \\
\text { promoting breastfeeding for HIV-infected women }\end{array}$} \\
\hline $\begin{array}{l}\text { a. Provides a reliable source of nutrition for } \\
\text { infants and can decrease malnutrition }\end{array}$ & 57 & 89.1 \\
\hline $\begin{array}{l}\text { b. Risk of HIV transmission remains; reinstate } \\
\text { the distribution of free formula milk }\end{array}$ & 4 & 6.3 \\
\hline c. Others & 3 & 4.7 \\
\hline
\end{tabular}

respondents indicated that they did it very regularly $(\mathrm{n}=28$; $43.8 \%)$ or daily $(n=20 ; 31.3 \%)$.

When the respondents were questioned regarding their confidence to demonstrate to a new mother how to breastfeed according to the correct positioning and attachment principles, nearly two thirds of them had a high level $(n=24 ; 37.5 \%) /$ very high level ( $n=23 ; 35.9 \%$ ) of confidence (Fig. 1). Similar results were found when respondents were asked to state their confidence in showing a mother how to express breast milk.

Based on professional status, the healthcare workers were grouped as nursing personnel $(\mathrm{n}=47 ; 73.4 \%)$ and doctors/dieticians ( $\mathrm{n}=17 ; 26.6 \%$ ). The only statistically significant difference (95\% CI for the percentage difference [2.1\%; 49.1\%]) between these two groups was their attitude towards HIVinfected women who feed their infants heat-treated expressed breast milk. The nursing personnel were more accepting of this feeding choice. Although statistically not significant, the nursing personnel were more confident in their ability to demonstrate to a new mother how to correctly position and latch a baby for breastfeeding (Table 3).

\section{Ethical considerations}

Approval for the study was obtained from the Ethics Committee of the Faculty of Health Sciences, University of the Free State (ECUFS 140/2011), the Chief Executive Officer of Pelonomi Regional Hospital, as well as the matron of the maternity wards. Respondents were requested to fill in the questionnaire anonymously after obtaining their written informed consent.

\section{Trustworthiness}

Validity was guaranteed as questionnaires were based on relevant literature and questions were motivated by scientific evidence. Reliability was ensured by providing short, userfriendly questionnaires in the preferred language, namely English, Afrikaans and Sesotho.

\section{Discussion}

\subsection{Knowledge related to infant feeding in the context of HIV}

According to the third principle of the 2010 WHO Guidelines on HIV and Infant Feeding, national health authorities should decide on a strategy where health services will principally counsel and support HIV-infected mothers to either breastfeed their infants together with anti-retroviral (ARV) interventions, or to avoid all breastfeeding (WHO, 2010a). It can

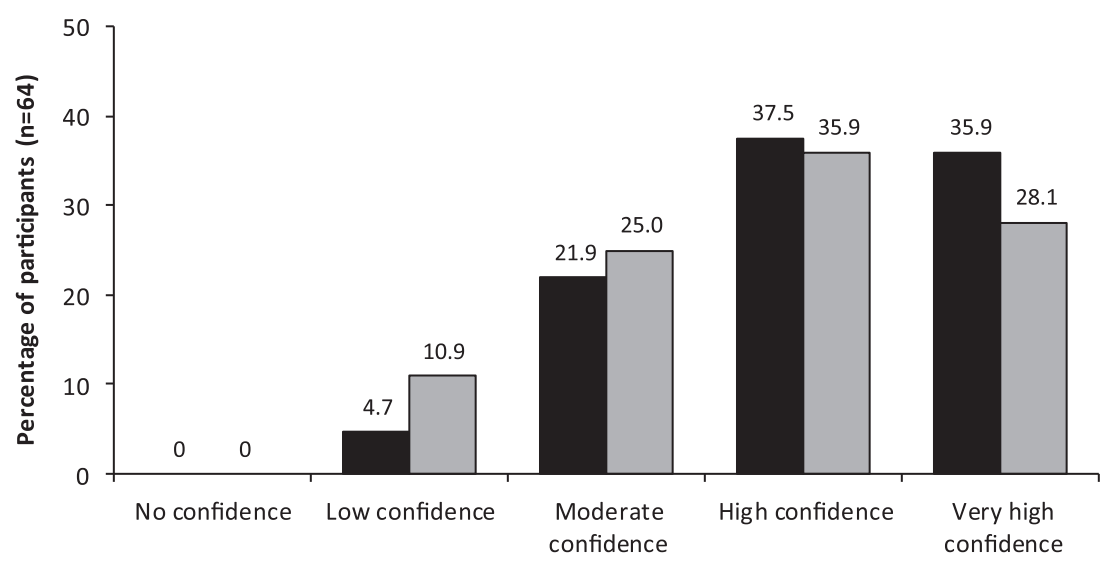

Show how to position and attach baby to breast $\square$ Show mother how to express breastmilk

Fig. 1 - Perceived confidence levels for counselling a mother regarding positioning and latching of a baby for breastfeeding, as well as breast milk expression indicated as percentage (\%) of healthcare workers. 
Table 3 - Association between professional status and issues relating to infant feeding in the context of HIV.

Variables to test opinions by professional status
Professional group

\begin{tabular}{|c|c|c|c|c|c|}
\hline & & \multirow{3}{*}{ difference } \\
\hline & \multicolumn{2}{|c|}{ Nurses $(\mathrm{n}=47)$} & \multicolumn{2}{|c|}{ Doctors/dieticians $(\mathrm{n}=17)$} & \\
\hline & $\mathrm{n}$ & $\%$ & $\mathrm{n}$ & $\%$ & \\
\hline Felt it was a good idea to heat-treat expressed breast milk & 25 & 53.2 & 4 & 23.5 & {$[2.1 \% ; 49.1 \%]^{*}$} \\
\hline $\begin{array}{l}\text { Had low confidence in showing a new mother how to } \\
\text { correctly position and latch the baby for breastfeeding }\end{array}$ & 10 & 21.3 & 7 & 42.2 & {$[-44.5 \% ; 3.9 \%]$} \\
\hline $\begin{array}{l}\text { Indicated correct age of an infant up to which } \\
\text { an HIV-infected mother can breastfeed, according } \\
\text { to } 2010 \text { WHO guidelines }\end{array}$ & 13 & 27.7 & 4 & 23.5 & {$[-21.9 \% ; 24.0 \%]$} \\
\hline $\begin{array}{l}\text { Perceived themselves to be highly knowledgeable } \\
\text { regarding infant feeding and HIV }\end{array}$ & 26 & 55.3 & 7 & 41.2 & {$[-12.7 \% ; 37.8 \%]$} \\
\hline
\end{tabular}

be argued that knowledge will form the basis of this process of counselling. It is, therefore, expected that each healthcare worker should have an optimum level of knowledge regarding infant feeding and HIV, especially the ones working in the maternity wards. However, only a few (14.1\%) of the healthcare workers included in the current study considered themselves to be experts regarding these issues. Shah, Rollins, and Bland (2005) conducted a rapid assessment of the breastfeeding knowledge of healthcare workers in KwaZulu-Natal Province in South Africa, an area with rather high prevalence of HIV, and found significant gaps in breastfeeding knowledge when compared to the (then current) WHO recommendations. Murila et al. (2015) assessed breastfeeding and HIV knowledge among clinicians in Kenya and concluded that the majority of respondents exhibited an inadequate knowledge. The authors recommended more intensive training for healthcare workers.

The WHO promotes EBF for the first six months of life, which requires that the mother must provide only breast milk, that she must breastfeed on demand and that no teats or pacifiers should be given to the infant (WHO, 2015). When the respondents were enquired to explain the term EBF, only $6.7 \%$ could comprehensively explain the concept as described by the WHO. Piwoz et al. (2006) experienced contrasting findings when healthcare workers were interviewed in Malawi; 18 out of 19 (94.7\%) healthcare workers correctly defined EBF. However, the criteria used for the definition were not indicated which could have differed from the ones used in the current study. The comprehension of what EBF entails should be central to the healthcare workers and mothers' knowledge related to infant feeding in the context of HIV infection to promote lower postnatal HIV transmission rates.

Nearly all the respondents were aware of the fact that EBF should continue till the age of six months. In a 2002 Cochrane review (Kramer \& Kakuma, 2002) regarding the optimal duration of EBF, it had been concluded that when an infant was exclusively breastfed for six months, the risk of infections was reduced, the infants showed no growth faltering, and the mother was more likely to experience lactational amenorrhoea which facilitates child-spacing. It is because of these factors that the WHO recommends six months of EBF, rather than the three to 4 months as per the previous recommendations. A contrasting finding was made in 2005 by researchers from the Ivory Coast, where healthcare workers would advise the HIV-infected breastfeeding mother to wean the child at the age of four months. One of their motivations for this recommendation was to decrease the duration of breastfeeding and thereby decrease the risk of postnatal HIV transmission (Becquet et al. 2005). Although intended for the general population as a global public health recommendation, it was already stated in the 2003 WHO document (Global Strategy for Infant and Young Child Feeding), that infants should be breastfed exclusively for the first six months of life (WHO, 2003a), indicating a trend towards a longer period of breastfeeding. In a KwaZulu Natal study in South Africa, Shah et al. (2005:33) also found that the majority of healthcare workers were prone to recommend water, formula or solid foods for breastfed infants under the age of six months. This approach reflects a definite lack of knowledge, which may lead to decreased effectiveness of PMTCT programmes.

Although the optimal duration of specifically exclusive breastfeeding was very well known to the respondents in the current study (six months), knowledge regarding the potential total duration of breastfeeding was lacking. When healthcare workers were asked to specify up to what age an HIV-exposed infant could potentially be breastfed, almost one third incorrectly answered up to the age of one year, and $17.2 \%$ incorrectly indicated up to six months of age. The previous recommendation that existed in this regard was for EBF to take place "during the first months of life" and then to be discontinued as soon as was feasible (WHO, 2003b). The newest guidelines (2010 WHO Guidelines on HIV and Infant Feeding, recommendation 2) state that mothers should breastfeed exclusively for six months (with infant ARV prophylaxis), then introduce appropriate complementary foods and continue to breastfeed for the first twelve months of life. It is important to note that after this period, breastfeeding should only cease once a "nutritionally adequate diet without breast milk can be provided" (WHO, 2010a). Thus, only $26.6 \%$ of the respondents were aware of the potential total period of breastfeeding of an HIV-exposed infant. One of the possible causes for the confusion is the emphasis that has always been laid on avoiding mixed feeding. The newest guidelines allow for mixed feeding after the age of six months - however, ARV prophylaxis should be used following standard protocols to decrease the risk of HIV transmission. This was decided after it had been made clear that early cessation of breastfeeding was not conducive for the infant's good health (WHO, 2010a). 
Most of the respondents in the current study could correctly indicate that, in general, infants who are formulafed have a higher risk for morbidity and mortality from causes other than HIV. Infants who are breastfed usually have a much lower risk of dying from diarrhoea, acute respiratory infections and other diseases. A non-breastfed infant has a fourteen times higher risk of dying in the first six months of life than an exclusively breastfed infant (UNICEF, 2014). Unhygienic preparation of infant formulae is one of the main reasons for infection, diarrhoea and malnutrition. Veldman and Brink (2004) collected formula milk samples for investigating the microbiological safety of 200 infant feeding bottles in the same area as the current study (Mangaung, Bloemfontein). Of these samples, $84.5 \%$ were classified unfit for human consumption due to high bacteria counts. The findings emphasise the need for adequate training of healthcare workers to ensure that correct and sufficient information on infant feeding reaches the mothers in order to curb the risk of infections in the infants.

In the current study, respondents' knowledge regarding the risks of postnatal transmission was also assessed. The risk of mother-to-child transmission (MTCT) is in the range of $20-45 \%$ without intervention, and the risk of postnatal transmission through breastfeeding can be decreased to $5 \%$ or less when specific intervention strategies, such as ARV therapy and correct breastfeeding practices, are implemented (WHO, 2010b). Most of the respondents correctly indicated a higher risk of transmission if ARVs are not used and if the mother does not breastfeed according to the guidelines. Similarly, $70.3 \%$ of them indicated a lowered risk of infection if guidelines are indeed followed. A considerable proportion of the healthcare workers (20.3\%) believed that there would be no risk of HIV transmission if the mother used ARVs and practised breastfeeding according to the guidelines. Although, by breastfeeding according to the guidelines, the risk of HIV transmission can be lowered significantly, it is not completely risk-free. It would be imprudent to communicate this to HIV infected patients who have a right to unambiguous information. Regarding the issue of mixed feeding, $10.9 \%$ of the respondents disagreed with the well-known fact - or were unaware - that mixed feeding increases HIV transmission risk.

\subsection{Opinions related to infant feeding in the context of HIV}

On the whole, healthcare workers included in the current study did not opine negatively regarding HIV-infected mothers who breastfeed their infants; almost all the respondents agreed that breast milk is an excellent feeding choice for their infants. Not even a single healthcare worker indicated that these mothers should not breastfeed due to the risk of HIV transmission. This finding was in contrast to a study from Ethiopia where healthcare workers were found to have a negative attitude towards HIV-infected mothers planning to breastfeed their infants, and they would also defend their promotion of formula feeding. Many healthcare workers even expressed great satisfaction when the mothers counselled by them abstained from breastfeeding, as they felt this would 'save the child from HIV infection' (Koricho et al., 2010). In Malawi, Piwoz et al. (2006:4) reported contrasting results.
Most of the healthcare workers with counselling experience who were interviewed in their study would encourage HIVinfected mothers to breastfeed exclusively rather than formula feed their infants. They cited poverty as the main reason for not encouraging the use of formula milk. Further, high levels of malnutrition are prevalent in Malawi and all of the healthcare workers were concerned about the early cessation of breastfeeding and the possibility of subsequent malnutrition. With almost all of the participants in the current study viewing breastfeeding as a favourable option, the foundation for accepting and promoting breastfeeding has already been established.

Most of the respondents included in the current study supported the new South African guidelines which promote breastfeeding together with ARVs as the main feeding option for HIV-exposed infants (Department of Health, 2011). They believed it would provide a reliable source of nutrition for infants in impoverished communities. Even though the previous free distribution of formula milk resulted in numerous problems in PMTCT programmes in developing countries, including South Africa (Coutsoudis, Goga, Rollins, \& Coovadia, 2002), 6.3\% of healthcare workers regarded this as a good option for mothers and would like to see it implemented at clinics again. Although most of the respondents (76.6\%) acknowledged the importance of considering the well-known AFFAS criteria (Adegbehingbe, Paul-Ebhohimhen, \& Marais, 2012) when evaluating the possibility of a mother safely providing formula milk to her infant, $10.9 \%$ of the them did not regard these criteria with the same level of priority. These respondents' main concern was in decreasing postnatal HIV transmission risk by abstaining from breastfeeding, and providing the infant with formula milk. This finding highlights a degree of ignorance regarding the significance of these very important criteria designed to protect the infant against unsafe formula-feeding practices. The 2015 National Consolidated Guidelines for the Prevention of Mother-to-Child Transmission of HIV and the Management of HIV in Children, Adolescents and Adults clearly states that the South African Department of Health promotes breastfeeding and ART use in HIV-infected mothers. HIV-infected mothers should be advised that formula milk will not be routinely provided in South Africa (Department of Health, 2015).

Heat-treated expressed breast milk has been proposed as a feeding option for infants of HIV-infected mothers, since the virus would be inactivated if the heat-treatment is done correctly. However, insufficient evidence is available to demonstrate the acceptability and sustainability of heattreated expressed breast milk at the community level (WHO, 2010a). According to recommendation 6 of the 2010 WHO Guidelines for HIV and Infant Feeding, this feeding method can be used as an interim infant feeding strategy, under the circumstances when a mother is temporarily unable to breastfeed her infant (WHO, 2010a). Almost half of the healthcare workers in the current study believed that this feeding strategy was a good option for such mothers. Another sizeable proportion of respondents $(29.7 \%)$ agreed with the WHO recommendation that, although it might be a useful option, most of the mothers would not be able to sustain this practice because of the amount of work involved at the time of each feed. Some of the respondents $(12.5 \%)$ considered this to 
be a bad option - probably due to a degree of scepticism in the effectiveness of this practice to kill the virus - or they felt that the limitations outweighed the possible advantages. Consequently, the results indicate that at least $42.2 \%$ of healthcare workers would probably not promote this practice to their patients.

The nursing personnel expressed significantly greater acceptance for feeding the infants heat-treated expressed breast milk than the doctors/dietician group (95\% CI [2.1\%; 49.1\%]). Perhaps the nurses realised the challenges faced by that mothers in formula feeding better than the other healthcare workers, since they are far more closely involved with the mothers. If the doctors/dieticians also understand the problems that may arise when a mother proposes to formula feed or breastfeed her infant, they might view heattreated expressed breast milk in a different light. However, it needs to be remembered that due to insufficient data to support the acceptability and feasibility of this strategy, even the WHO has stated that it cannot be promoted for all HIVinfected mothers who opted for breastfeeding (WHO, 2010a).

\subsection{Practices related to infant feeding in the context of HIV}

The healthcare workers in the maternity wards regularly provided advice to HIV-infected mothers regarding infant feeding. The fact that most healthcare workers did indeed spend a significant amount of time in counselling and advising the mothers on infant feeding itself, emphasises the importance of their being very well informed regarding the issues related to this aspect. They should also be able to demonstrate easily to a mother how to breastfeed and express the breast milk correctly; although, only $35.9 \%$ and $28.1 \%$, respectively expressed a very high level of confidence in doing so. The finding indicate that a lack of practical application of knowledge exists among the healthcare workers.

\section{Limitations}

This study was limited to one hospital in Bloemfontein, and thus the findings cannot be generalised to healthcare facilities elsewhere. The results do however provide a snapshot of the current state of healthcare workers' knowledge, and can be used as a pilot study for further research.

\section{Recommendations}

The main implication emanating from this research includes upgrading the training for the healthcare workers, since an inadequate level of knowledge was uncovered in the current study. Their training should follow an intensive and structured approach, with opportunities for discussions and sharing of personal experiences. Training should not only be provided for practising healthcare workers, but students in healthcare professions should also be educated to equip them with the necessary knowledge they will need to counsel effectively. Providing scientifically correct, unbiased information is fundamental during infant feeding counselling sessions and public health education to ensure the success of PMTCT programmes. The design and distribution of updated, interesting, interactive educational materials could contribute to the successful implementation of PMTCT programmes and should be addressed urgently. Both the healthcare workers and the patients will benefit from improved training sessions and effective educational materials, as these can promote the transfer and retention of vital information. A strategy that needs to be considered is the development of a core curriculum of educational material based on WHO and South African PMTCT guidelines. Healthcare workers should be trained using these information, education and communication (IEC) materials suitable for local environments to improve acceptability and success of the training programme. Healthcare workers should be trained not only in facts and information, but also in counselling skills which can build trust and encourage honesty in the healthcare worker/patient relationship.

Further research into the methods and effectiveness of the training of healthcare workers in South Africa should receive attention. The barriers that impede success of the counselling sessions could also be determined in order to develop strategies to overcome the same leading to better outcomes of PMTCT programmes. Improved knowledge of the healthcare workers will enable them to guide and educate the mothers appropriately for achieving the ultimate goal of improved infant and child health.

\section{Conclusion}

The knowledge, opinions and practices of healthcare workers associated with infant feeding in the context of HIV were assessed. Gaps in knowledge regarding some basic concepts and practices were noted. It however seemed as though the healthcare workers were accepting HIV-infected mothers to breastfeed their infants and they acknowledged the fact that correct breastfeeding practices could be a safer option than formula feeding for many of these women. This research contributes to the literature by providing insight into the healthcare workers' current level of knowledge as well as opinions and practices regarding issues related to HIV and infant feeding.

\section{Significance of work}

The main implication emanating from this research includes the upgrading of training to healthcare workers in the field of HIV and infant feeding, since an inadequate level of knowledge was uncovered in the study. The subsequent provision of high quality counselling to HIV-infected women can improve their knowledge and lead to better infant feeding decisions being made. These actions will ultimately benefit the mother, her infant, and the community at large.

\section{Authors' contributions}

This article is based on research done by L.JvR. (University of the Free State), under supervision of C.W. (University of the 
Free State). R.N. (University of the Free State) provided input in the protocol and was responsible for the statistical analysis of the data.

\section{Acknowledgements}

The authors hereby thank the participants for partaking in the study. Dr. Daleen Struwig, medical writer, Faculty of Health Sciences, University of the Free State, is acknowledged for technical and editorial preparation of the manuscript.

\section{R E F E R E N C E S}

Adegbehingbe, S. M., Paul-Ebhohimhen, V., \& Marais, D. (2012). Development of an AFASS assessment and screening tool towards the prevention of mother-to-child HIV transmission (PMTCT) in sub-Saharan Africa - a Delphi survey. BMC Public Health, 12(402), 1. http://dx.doi.org/10.1186/1471-2458-12-402.

Becquet, R., Ekouvi, D. K., Sakarovitch, C., Bequet, L., Viho, I., Tonwe-Gold, B., et al. (2005). Knowledge, attitudes and beliefs of healthcare workers regarding alternatives to prolonged breastfeeding. Journal of Acquired Immune Deficiency Syndrome, 40, 102-105.

Cai, X., Wardlaw, T., \& Brown, D. W. (2012). Global trends in exclusive breastfeeding. International Breastfeeding Journal, 7 , 12. viewed on 31 July 2015, from http://www. internationalbreastfeedingjournal.com/content/7/1/12.

Coutsoudis, A., Goga, A. E., Rollins, M., \& Coovadia, H. M. (2002). Free formula milk of HIV-infected women: blessing or curse? Health Policy and Planning, 17(2), 154-160. http://dx.doi.org/10. 1093/heapol/17.2.154.

Department of Health (DoH). (2011). Media statement by the Minister of Health Dr. Aaron Motsoaledi: Government adopts breastfeedingonly infant feeding strategy, media release. South Africa: National Department of Health. viewed 15 November 2011 from http:// www.gov.za/media-statement-minister-health-dr-aaronmotsoaledi-government-adopts-breastfeeding-only-infant.

Department of Health (DoH). (2015). National consolidated guidelines for the prevention of mother-to-child transmission of HIV and the management of HIV in children, adolescents and adults. Pretoria.

Koricho, A. T., Moland, K. M., \& Blystad, A. (2010). Poisonous milk and sinful mothers: the changing meaning of breastfeeding in the wake of the HIV epidemic an Addis Ababa, Ethiopia. International Breastfeeding Journal, 5(12), 1-8. viewed on 06 August 2014, from http://dx.doi.org/10.1186/1746-4358-5-12.
Kramer, M. S., \& Kakuma, R. (2002). Optimal duration of exclusive breastfeeding (Review). Cochrane Database of Systematic Reviews, 1, 11-12. http://dx.doi.org/10.1002/14651858. CD003517.

Mnyani, C. N., \& McIntyre, J. A. (2013). Challenges to delivering quality care in a prevention of mother-to-child transmission of HIV programme in Soweto. Southern African Journal of HIV Medicine, 14(2), 68.

Murila, F., Obimbo, M. M., Musoke, R., Tsihutsu, I., Migiro, S., \& Ogeng'o, J. (2015). Breast-feeding and human immunodeficiency infection: assessment of knowledge among clinicians in Kenya. International Journal of Nursing Practice, 21, 37-42.

Piwoz, E. G., Ferguson, Y., Bentley, M. E., Corneli, A. L., Moses, A., Nkhoma, J., et al. (2006). Differences between international recommendations of breastfeeding in the presence of HIV and the attitudes and counselling messages of health workers in Lilongwe, Malawi. International Breastfeeding Journal, 1(2), 1-8. viewed on 07 August 2014, from http://dx.doi.org/10.1186/ 1746-4358-1-2.

Shah, S., Rollins, N., \& Bland, R. (2005). Breastfeeding knowledge among health workers in rural South Africa. Journal of Tropical Pediatrics, 51(1), 33-38. http://dx.doi.org/10.1093/tropej/ fmh071.

United Nations Children Fund (UNICEF). (2014). Infant and young child feeding. viewed 28 January 2014, from http://www.unicef. org/nutrition/index_breastfeeding.html.

Vallely, L. M., Kelly, A., Kapul, M., Neo, R., Kaldor, J. M., Mola, G. D. L., et al. (2013). Infant feeding in the context of HIV: a qualitative study of health care workers knowledge of recommended infant feeding options in Papua New Guinea. International Breastfeeding Journal, 8(6), 1-8. viewed on 07 August 2014, from http://dx.doi.org/10.1186/17464358-8-6.

Veldman, F. J., \& Brink, J. D. (2004). Implications of formula feeding to reduce HIV transmission. Southern African Journal of HIV Medicine, 5(3), 38-41.

World Health Organization (WHO). (2003a). Global strategy for infant and young child feeding. Geneva: WHO.

World Health Organization (WHO). (2003b). HIV and infant feeding guidelines for decision-makers. Geneva: WHO.

World Health Organization (WHO). (2010a). Guidelines on HIV and infant feeding. Geneva: WHO.

World Health Organization (WHO). (2010b). PMTCT strategic vision 2010-2015: Preventing mother-to-child transmission of HIV to reach the UNGASS and Millennium development goals. Geneva: WHO.

World Health Organization (WHO). (2015). Exclusive breastfeeding. viewed 03 August 2015, from http://www.who.int/nutrition/ topics/exclusive_breastfeeding/en/. 